Al-Uqud: Journal of Islamic Economics E-ISSN 2548-3544, P-ISSN 2549-0850 Accredited No. 28/E/KPT/2019
Volume 4 Issue 1, January 2020

DOI:10.26740/al-uqud.v4n1.p18-31

Page 18-31

\title{
Survival of Traditional Retailers: An Islamic Business Perspective
}

\author{
Lilik Rahmawati ${ }^{1}$, Mutimmatul Faidah ${ }^{2 *}$ \\ ${ }^{1}$ Department of Islamic Economics, Faculty of Economics and Islamic Business, \\ Universitas Islam Negeri Sunan Ampel. Jalan Ahmad Yani, Surabaya 60237, Indonesia \\ ${ }^{2}$ Department of Home Economic Education, Faculty of Engineering, Universitas Negeri \\ Surabaya. Jalan Ketintang, Surabaya 60231, Indonesia
}

\begin{abstract}
This study aimed to explain the reality of survival mechanisms and adaptive strategies by traditional retailers in Surabaya in facing the existence of massive modern retail stores. This study used qualitative research with a phenomenological approach. The data collection method used observation and interview techniques. Data analyzed with Clark and Scott's survival mechanism theory and the adaptive strategy by Miles and Snow. The result of this research was in the aspect of defender strategy, traditional retailers did various strategies when prices went up, and instead of increased the prices they choosed to reduce the profits. The stores equipped with people daily needs to retain customers. Even though the stock was small, the items sold were complete. It was important to promote family relations with buyers. A striking aspect is the close family relation that was so different from modern retail stores. In the aspect of reactor strategy, the owners responded to the situation without having a long-term strategy design. Their store's responses were reactive and short-term oriented in the form of selling goods by following the tastes of buyers and current trends. Meanwhile, in carrying out business performance in connection with the survival mechanism, Surabaya traditional retailers met the business assessment of the Islamic perspective namely on the aspects of material, mental, spiritual, and fraternal.
\end{abstract}

Keywords: Traditional retail store; Modern retail stores; Survival mechanism; Defender strategy; Islamic perspective.

Paper type: Research paper

*Corresponding author: mutimmatulfaidah@unesa.ac.id

Received: December 12, 2019; Accepted: January 10, 2020; Published: January 20, 2020

Cite this document: Rahmawati, L. \& Faidah, M. (2020). Survival of Traditional Retailers: An Islamic Business Perspective. Al-Uqud: Journal of Islamic Economics, 4(1), 18-31. doi: http://dx.doi.org/10.26740/al-uqud.v4n1.p18-31

Copyright $@$ 2020 , Al-Uqud: Journal of Islamic Economics

http://journal.unesa.ac.id/index.php/jie 


\begin{abstract}
Abstrak: Penelitian ini bertujuan mendeskripsikan realitas mekanisme survival dan strategi adaptif yang dilakukan pemilik toko kelontong Surabaya dalam menghadapi eksistensi minimarket modern. Pendekatan yang dipilih adalah kualitatif. Pengumpulan data dengan wawancara dan observasi. Data dianalisis menggunakan teori survival mechanism oleh Clark dan James C Scott's, dilengkapi teori adaptive strategy oleh Miles dan Snow. Hasil penelitian ditemukan bahwa strategi adaptif yang dilakukan oleh Pemilik toko kelontong Surabaya dalam menghadapi persaingan dengan toko kelontong adalah pada aspek defender strategy dan reactor strategy. Pada aspek defender strategy, Pemilik toko kelontong Surabaya melakukan berbagai strategi, saat harga naik, toko kelontong tidak ikut menaikkan harga namun cukup mengurangi keuntungan yang didapat; mempertahankan pelanggan dengan cara melengkapi toko dengan kebutuhan sehari-hari warga; mengedepankan hubungan kekeluargaan dengan pembeli. Hal yang menonjol pada aspek ini adalah adanya hubungan kekeluargaan yang begitu akrab berbeda dengan toko ritel modern. Pada aspek reactor strategy yaitu merespon lingkungan tanpa memiliki rancangan strategi yang bersifat jangka panjang, respon toko kelontong bersifat reaktif dan berorientasi jangka pendek dalam bentuk menjual barang dengan mengikuti selera pembeli dan trend kekinian. Dalam menjalankan kinerja bisnis sehubungan dengan mekanisme survival pemilik toko kelontong Surabaya menghadapi eksistensi minimarket modern memenuhi kinerja bisnis perspektif Islam yaitu pada aspek kinerja material, aspek kinerja mental, aspek kinerja spiritual, dan aspek kinerja persaudaraan.
\end{abstract}

Kata kunci: Toko kelontong; Ritel modern; Mekanisme bertahan hidup; Strategi bertahan; Perspektif Islam.

\title{
INTRODUCTION
}

Recently, the existence of traditional retail stores in Surabaya is alarming in which existing modern stores begin to be massive. Per the Department of Communication and Information of Surabaya City, the number of modern retail stores in Surabaya is about 573 stores spread in different locations. There are 172 stores in South Surabaya, 62 stores in Central Surabaya, 72 stores in North Surabaya, 193 stores in West Surabaya, and 174 stores in East Surabaya. These typical modern retail stores include several stores' brands such as Indomaret, Alfamart, Alfamidi, and Circle K (Dinkominfo of Surabaya, 2018).

The phenomenon might grow more massive and multiply by numbers due to legal procedures of developing such business. In Indonesia, the business of modern retail stores has been regulated under the Ministry of Trade Regulation Number 70 the Year 2013 and Indonesian Presidential Regulation Number 112 the Year 2007 concerning regulating traditional markets, shopping centers, and modern stores. These regulations have set specific proportions related to the ownership of outlets and the composition of the sale products. Indonesian Ministry of Trade Regulation Number 53 the Year 2008 also stipulates the establishment mechanism of modern retail stores that must consider the nearby traditional stores and stalls (Permendag of Indonesia, 2013).

However, the fact shows on the contrary where numbers of modern retail stores are established more massively. In Surabaya, almost all the ways along the city streets have modern retail stores, of which they seemingly do not obey the existing regulation to give traditional stores space to exist and develop. For 
example, there are four big modern retail stores namely Alfamart and Indomaret existing along the 1-kilometers street of the campus area at UIN Sunan Ampel Surabaya. Tragically, these stores are built beside a few existing traditional retail stores.

Traditional retail stores sell low-price daily necessities and are located on the edge of roads so that everyone might access them easily. Most traditional retail stores pay less attention to the display of goods so that it seems cluttered. Moreover, the services tend to be less friendly (Anupam et al. 2010). In 2018, Surabaya Trade Official coordinated and fostered all traditional retail stores that had cooperation with the Faculty of Economics and Business at UIN Sunan Ampel Surabaya. According to data from Surabaya Trade Official in 2018, 2065 traditional retail stores were recorded in the coordination and guidance of the Trade Service spread in 31 sub-districts throughout Surabaya city (Disperdagin of Surabaya, 2019).

Many studies have been conducted on revealing the impact of the existing modern retailers on the development of traditional retailers. Anupam et al (2010), showed that the modern market outperformed over the traditional market for the overall retail service quality scale. Furthermore Prabowo \& Rahadi (2015) successfully generated the relevant categories in influencing the store loyalty attributes for the younger generation when they are shopping in the traditional marketplace in Indonesia. Moreover, another study was carried out by Schipmann \& Qaim (2011) that generated the rapid expansion of modern retailers seems to be more associated with the growth of high-quality, differentiated market segments than the direct competition for traditional market shares. The results of most studies concluded that the existence of modern retail stores had an impact on the economy flows of traditional retail stores.

By referring the facts, a study in revealing the survival mechanism of Surabaya traditional retail stores needs to be conducted. The selection of Surabaya as the locus of this research is based on the fact that the Government of Surabaya City through the Surabaya Trade Official has conducted a series of softkill and hard skill training for Surabaya traditional retail traders. The Government of Surabaya City also initiated the formation of cooperatives in each sub-district. The cooperative consists of traditional retail trader's with a supervisor from the Surabaya Trade Official. These efforts were made with the aim that the traditional retail in Surabaya could survive and develop. (Disperdagin of Surabaya, 2019). Survival can be understood as an effort to stand and get out of any difficulties. Moreover, the survival mechanism is people's ability to apply a set of ways to overcome various problems existing in their lives (Sunanto, 2012). Two Western figures are discussing individual survival mechanisms namely Clark and Scott, who also become the initiators of the raising theory of survival mechanisms. However, each of them has differences perspective in a person's survival mechanism.

Clark argues that if someone improves economic conditions, then there must be several strategies carried out. The strategies adopted include, first, a mutual exchange of money, goods, and services to meet daily and sudden needs. The second strategy is changing the composition of the household members by leaving the children with their grandmother in the village. Third, it is diversifying business 
sources, for instance, working in the informal sector. The last strategy is getting around the shortcomings in meeting people's needs by utilizing social capital such as making loans (Clark, 2019).

Clark's perspective is quite different from Scott. Scott believes that there are several ways in which the poor can survive. The steps encompass, first, reducing several spendings on food by eating only once a day and switching the current food quality to lower quality. Second, it is necessary using alternative subsystems through activities such as small-scale selling, working as a handyman or a freelance worker, and migrating to find better jobs. The third way is asking for help from social networks such as relatives, village friends, or takes advantage of relationships with patrons (Scott, 2010).

Of the two experts above who introduce the concept of survival mechanism, the difference lays in the attitude of reducing family expenses. Clark believes the way to do is by changing the composition of the family members by leaving the child to another family. Whereas, Scott believes that by eating only once and switching to lower quality food can help decrease family expenses (Scott, 2010)

It seems that Scott's theory related to the method of reducing family expenses by eating only once is already irrelevant to see the survival mechanism. Therefore we must refer to other theories, for example, the concept of adaptive strategies introduced by Miles and Snow. Miles and Snow state that there are various strategic steps performed by traders or entrepreneurs in business competition namely prospector, reactor, survival, and analysis strategies (Blackmore \& Nesbitt, 2013). Besides, W. Chan Kim and his colleague from France Renee Mauborgne introduce Blue Ocean Strategy theory, a strategy to conquer competitors through offering innovative product features, which so far have fewer competitors' attention. By using the aforementioned theory, a study in depicting the survival mechanism of traditional retail stores in Surabaya can be undertaken.

To the best of the researchers' knowledge, studies in revealing traditional retail stores' survival mechanisms have been carried out by both national and international researchers. Some of the researches are Boyd \& Kurov (2012), Ringwald \& Parfitt (2011), and Ashworth (2012). The difference between this study and previous studies lies in the scope of the study, the location of the study, and the theories used for analysis.

Although the present study is not new, the presence of this study will complement the previous survival mechanism theory since this study also reveals the adaptive strategies of traditional retailers in dealing with the existence of modern retail stores. Therefore, this study was conducted phenomenological by directly dealing with each stores' owner. The survival mechanism theory used was that of from Clark and Scott.

The theory of survival mechanism introduced by Scott is the one that consists of three ways in which poor people survive namely: first, reducing spending on foods by eating only once a day and switching to lower food quality; second, using alternative subsystems including opening stalls, working as a handyman or a freelancer, and migrating to find better job opportunities. This method can involve the presence of wives who can work and support the husbands to make a living; third, asking for help from social networks such as relatives and friends, or taking 
advantage of relationships with patrons. The relationship between patron and its clients (laborers) can be a form of insurance among farmers. Patrons are, by definition, people who are in a position to help their clients. Patrons are capital owners who can help farmers with financial assistance (Scott, 2010).

The survival mechanism in Clark's theory refers to an attempt and strategy undertaken by a woman to improve her economic condition such as the strategy is in a form of mutual exchange in money, goods, and services to meet people's daily and sudden needs. The social networks include close relatives, neighbors, and coworkers (informal social support networks). Another strategy is for those who are married and aim to change the composition of the family members by leaving the children with their grandmother in the village so that they can reduce the living expenses in the city (flexible household composition). The next strategy is namely business-source diversification, for example, working in the informal sector or opening services and shops. The third strategy is carried out due to limited times, skills, capitals, and information obtained (multiple sources of income). The last strategy is done by overcoming the shortcomings in meeting the living needs using social capital assets by making loans (utilizing informal credit and bank debt) (Clark, 2019).

In addition, Miles and Snow's theory of survival mechanism was chosen to complement the adaptive theory to strengthen the analysis. The concept of adaptive strategy is introduced by Miles and Snow in which the strategy is developed based on the situation faced by the company in a business competition. In this strategy, there are four types of strategy models encompassing: first, prospector strategy, which includes daring to take risks, looking for opportunities, and doing innovation and development. This strategy is suitable for a dynamic business environment. Second, defender strategy, which includes avoiding change, prioritizing stability, and considering reducing business size. This strategy is suitable for a stable business environment and a downturn industry. Third, reactor strategy, which response to the environment without having a long-term design strategy. The company is only reactive and short-term oriented. Fourth, the analyzer strategy, which is maintaining stability while carrying out limited innovations. This strategy lies between prospectors and reactor strategies. This strategy is usually carried out by companies that do not become market leaders, but followers. In this strategy, the company will follow the leader, but also make innovations that are not intensive while waiting for industrial development (Blackmore \& Nesbitt, 2013).

Besides, this study also used Blue Ocean theory to uncover the defeat causes of traditional retail stores in competing with modern ones. Blue Oceans Theory is the brainchild of Korean professor W. Chan Kim and his French counterpart Renee Mauborgne. Blue Ocean Strategy is basically a strategy to conquer competitors by offering innovative product features, which so far have fewer competitors' attention (Randall, 2015). The features of this product are usually radically different from those that already exist and are available on the market. What practitioners in today's creative industry do is creating radically different innovative product features. In connection with the application of Blue Oceans' strategy, businessmen are encouraged to enter a new market arena that has the potential to be overlooked by competitors. In this strategy, there are four steps of the strategy applied covering 
elimination, reducing, enhancement and creation, especially in an effort to distinguish the Blue Oceans profile from the general profile of the industry.

An effective Blue Oceans strategy has at least three complementary qualities namely focus, divergence, and the main motto. First, in connection with focus, every great strategy needs to have focus, where every strategic profile or company value curve must clearly show that focus. Second, divergence is a form of value curve that moves away from other competitors, such as an effort to find and see new alternatives without having to compare themselves with other competitors. When a company's strategy is formed reactively in an effort to follow the beat of the competition, then that strategy will lose its uniqueness. Third, an attractive, clear, and alluring motto would be a good strategy. In this case, the advertising agency will find it difficult to get a memorable motto from just a conventional offering in the form of lunch, seat choice, or a restoration menu. A good motto must not only be able to convey the message clearly but also advertise offers or products honestly. Henceforth, the effectiveness and strength of a strategy could be tested by seeing whether a strategy contains a strong and authentic motto.

In this study, the business performance of traditional retail stores in the context of facing modern retail stores was assessed based on the perspective of Islamic business performance. Islamic business performance was conducted by adapting to Javed's study.

Qardhawi explained that Islam views work as part of worship and jihad whether the worker is consistent with the rules given by Allah SWT, pure in intention, and not forgetting Him. By working, the community can carry out the tasks of the Caliphate, protect themselves from bad things, and achieve greater goals. Based on the Islamic perspective, it is illustrated that the performance orientation is not only to maximize profits under the use of conventional performance appraisal methods, but the performance orientation needs to encompass a broader and comprehensive dimension such as stakeholders' welfare including investors, employees, customers, suppliers, communities, societies, and future generations (Usman et al. 2015). Elements of performance appraisal that are in line with Islamic perspectives namely (Javed et al. 2017)

1) Material Performance

The assessment indicators in this element are sufficient profits to meet the needs of the household that are obtained honestly, do not harm others, and are used for investment for the survival of a company.

2) Mental Performance

The indicators in this assessment are that carrying out a job, ought to be carried out diligently and happily when enjoying the results obtained and fostering trust among people.

3) Spiritual Performance

The indicators in this assessment are closer to Allah SWT, which cover working as worship to Allah SWT, always being grateful for the results obtained, and remaining obedient and consistent with the rules and laws of Allah SWT. 


\section{4) Fraternal Performance}

The indicators in this assessment are creating harmonious social relations, both within the company and the community, meeting the needs of the community with halal products and services, and having high quality at affordable prices (Wahab, 2014).

This study was inspired by the phenomena of traditional retail stores in Surabaya during the mentoring activities carried out by the researchers in collaboration with the Faculty of Economics and Business of UIN Sunan Ampel Surabaya and Surabaya Trade Official. However, this study did not intend to explain the process and the results of the mentoring process carried out in traditional retail stores. The focus of the current study is to explain the reality of survival mechanisms and adaptive strategies carried out by Surabaya traditional retailers to face numbers of existing modern retail stores along with the supporting theories.

\section{RESEARCH METHODS}

This study used a qualitative method, which produced descriptive data in the form of written or oral words from people or actors that could be observed in a particular setting naturally (Willis et al. 2016). By using this method, the study intended to be able to understand the phenomena about what was experienced by subjects such as behavioral perceptions, motivations, actions, and others. Thus, the data collected in this study is more in the form of words or images than numbers (Tracy, 2017).

The present study used the interpretative phenomenological approach by Alfred Schutz, which was carried out by looking at the phenomena that occurred in recent social realities, for instance, a micro issue that turned into a macro problem. The interpretative phenomenological approach gives researchers the best opportunity to understand the innermost deliberation of the 'lived experiences' of research participants. As an approach that is 'participant-oriented', interpretative phenomenological analysis approach allows the interviewees (research participants) to express themselves and their 'lived experience' stories the way they see fit without any distortion and/or prosecution (Alase, 2017). In a qualitative study, the nature of reality was not only what was visible, but deeper into what beyond it. In this study, researchers tried to give an idea of how the tips and efforts of traditional retailers in Surabaya amid the rise of modern retail stores. Researchers also described the adaptive strategies of the traditional retailers to survive (Gros, 2017).

The location of this study was in Wonocolo District, Surabaya. The reason for choosing a location was due to the location of modern retail stores was not too far away, so it was very clear that there was direct competition between Surabaya traditional retailers the modern stores.

The informants of this study were 10 traditional retailers in Wonocolo District. Those were divided into 5 traditional retail stores in the Jemurwonosari Street area, Wonocolo District, which sold daily necessities among several Alfamart and Indomaret minimarkets in the region and 5 traditional retail storea in Margorejo Street area, Wonocolo District. The rationale for selecting the traditional retailers at Jemurwonocolo Street was since all the stores locate along 
the edge of the village street. Meanwhile, those at Margorejo Street were the representative of retailers who sell along the edge of the main road.

The data collection method used observation and interview techniques. The observation was used to collect data by observing the research object (Adhabi, 2017). Researchers conducted observations on the behavior of traditional retail stores in connection with survival mechanisms and adaptive strategies carried out in the face of competition with modern retail stores. Meanwhile, in-depth interviews aimed at revealing the details of the survival mechanism and adaptive strategies carried out in the face of competition with modern stores

The obtained data were analyzed using descriptive analysis techniques. This analysis technique started by studying the data obtained from several sources (Willis, 2016). Furthermore, researchers conducted the process of separating the interview results, or phenomenologically better known as coding and data categorization. The data reduction was conducted to find the focus of data that had been obtained from the field. Then, the data display was carried out. In a qualitative study, the data were presented in the form of brief descriptions, charts, and relationships between categories. The next stage was conclusion or verification, of which the initial conclusions were still temporary and would change once no strong evidence found to support the next stage of data collection (Alase, 2017).

\section{RESULTS AND DISCUSSION}

There were at least four kinds of modern retail stores, it means convenience stores in Surabaya such as Indomaret, Alfamart, Alfamidi, and Circle K which were spread over 573 locations (Dinkominfo of Surabaya, 2018). Hence, nowadays the traditional retail stores were not the only place to meet the needs of the people in Surabaya. Surabaya citizens no longer shop in traditional retail stores because modern stores such as Alfamart and Indomaret provided longer service hours compared to those traditional stores. In general, all traditional retail stores only operated from morning to evening. Some were until night, but the maximum was at 22.00 WIB. Now, traditional retail stores lost their popularity and existence. In meeting their daily needs, the urban community tent to prefer shopping for daily necessities in modern retail stores that self-service, clean shop conditions and friendly shopkeepers.

Modern retail stores such as Alfamart and Indomaret has become an inseparable part of the lives of Surabaya citizens. Indeed, this situation was not favorable for Surabaya's traditional retailers. Concerning this fact, traditional retailers in Surabaya did a survival mechanism. This study found that the survival mechanism by Clark and Scott was incompatible with that experienced by Surabaya traditional retailers. Scott looked at three ways that poor people survived such as reducing food spending by eating only once a day and switching to lower food quality. Then, using alternative subsystems which included activities such as operating small stalls, working as a handyman and a freelance worker, or migrating to find better job opportunities. This method could involve resources in poor households especially wives who also made a living. The last, asking for help from social networks such as relatives and friends, or taking advantage of relationships with patrons. 
According to the researchers' view, Scott's study related to survival mechanism could not answer the problem of survival of Wonocolo traditional retail stores in contending with the existence of modern stores. The fact that happened in Surabaya traditional retail stores, their survival mechanism did not use three strategy models as stated by Scott. This was because the focus of Scott's survival mechanism theory was the poor (Scott, 2010). Likewise, Clark's theory in studying survival mechanisms was also irrelevant in answering the issue of traditional retail stores' survival mechanisms. Clark's study focused on women's mechanisms for survival, meanwhile, the context of traditional retail stores was the competition with modern retail stores in urban areas (Clark, 2019). Thus, Miles and Snow's adaptive strategies were better for the present study.

Regarding the four concepts proposed in Miles and Snow's adaptive strategies which included prospector, defender, reactor, and analyzer strategies, the defender and reactor strategies were under the reality of Surabaya traditional retail stores in facing business competition with the modern retail stores. Defender strategy was to avoid change, prioritize stability, and consider reducing business size. This strategy was suitable for a stable business environment and a downturn industry (Blackmore \& Nesbitt, 2013). In the case of traditional retailers in the Wonocolo District, they preferred to survive even though they had felt a change in recent years. The strategy used in this condition was to reduce the stock of the number of products sold. The merchant's philosophy said "a few things that matter", of which this strategy was chosen by Wonocolo traditional retailers with various alternatives, such as:

First, when the price of goods was forced to go up, then the traditional retailers did not participate in raising prices but reducing the profits. Although the profits were reduced as well as the income, the important consideration was that they still could continue to sell and the stock of goods decreased. This step was quite effective because in buying products sold at traditional retail stores, buyers felt a fixed price when compared to those modern stores. So, buyers would feel better buying at the traditional retail stores again. Second, retaining the customers was carried out by equipping shops with their daily needs. Even though the stock was small, the items sold were complete. Third, traditional retailers tend to promote family relations with the buyers, for instance, by using everyday language. This method was quite effective, both buyers and customers felt comfortable when shopping.

Meanwhile, the reactor strategy responded to the environment without having a long-term strategy design. It means the owner of Surabaya traditional retail store is only reactive and short-term oriented. In the reality of Surabaya traditional retail stores, their responses were only reactive and short-term oriented. In this case, the development of buyer tastes was more prioritized. For example, when the Milo ice ball was booming, most Surabaya traditional retailers started to sell it too. The owners bought a Milo ice-making machine. When the Milo ice-making machine was no longer booming, the machine was then abandoned.

The existence of modern and traditional retail stores in Surabaya gave people two choices of places to meet their daily needs. Supported by a complete and increasingly sophisticated infrastructure and a variety of promos made the modern retail stores more attractive and slowly people left the traditional stores. Modern 
stores created a prestigious self-image, magnificent buildings, and friendly service. People no longer only thought about fulfilling their daily needs, but also gaining prestige and forming an idealized self-image by visiting a modern store.

Although the citizens of Surabaya still visited traditional retail stores in meeting their daily needs, the store's sales turnover was stagnant. The traditional retailers might get profit but not optimal. This could be observed from the rapidness of the development of each traditional retail store in Surabaya. The reality of Surabaya's traditional retail stores was the opposite of modern retail. The condition of the traditional retailers had been stagnant from its inception until now, so that, the concept of Blue Oceans' strategy was quite relevant in helping the stores. Blue Oceans was an important theme of the strategic management discourse of the past five years. It was the brainchild of Korean Professor W. Chan Kim and his French counterpart Renee Mauborgne.

Prabowo \& Rahadi (2015) found that traditional retail stores did not experience significant development due to the absence of innovation and creativity in business management. It showed that the younger generation has many categories when they are shopping in the traditional market in Indonesia. So innovation and creativity are very important. Blue Oceans Strategy was a strategy to conquer competitors by offering innovative product features. Today's advanced industries applied the strategy, which had at least three complementary qualities, namely focus, divergence, and the main motto. In connection with focus, every great strategy needed to have focus, where a strategic profile or company value curve must clearly show that focus. Second, regarding divergence, it was a form of value curve that moved away from other competitors namely an effort to find and see new alternatives without having to compare themselves with other competitors. When a company's strategy was formed reactively to follow the beat of the competition, then that strategy would lose its uniqueness. Third, an attractive, clear, and alluring motto became a good strategy. In this case, the advertising agency would find it difficult to get a memorable motto from just a conventional offering in the form of lunch, choice, or a restoration menu. A good motto must not only be able to convey the message clearly but also advertised offers or products honestly. So, the effectiveness and strength of a strategy could be tested by looking at whether a strategy contained a strong and authentic motto.

The reality of Surabaya's traditional retail stores was the opposite of the concept of Blue Oceans' strategy. Blue Ocean Strategy is a strategy to conquer competitors by offering innovative product features, which so far have fewer competitors' attention. The traditional retail stores did not experience significant development due to the absence of innovation and creativity in business management (Randall, 2015). The traditional retail stores did not focus on running their businesses but were considered a part-time livelihood. Therefore, the management was not good. The stores did not innovate, look for, and see new alternatives without having to compare themselves with competitors in developing their business. There were no promotional efforts on the product and store. The effect was that the traditional retail stores did not have a clear and alluring motto to compare with other stores. So that, traditional retail traders need to apply Blue Ocean Strategy. 
Meanwhile, in the perspective of Islamic business performance, Surabaya traditional retailers had been doing business following the working concept of Islam amid the massively existing modern retail stores because the store owners worked as part of worship (QS. Al-Jumah: 10). The performance orientation of Surabaya traditional retailers was not only to maximize profits, but also the welfare of stakeholders including employees, customers, suppliers, community, societies, and future generations. Profits obtained by Surabaya traditional store owners were sufficient to meet household needs, obtained honestly, not harming others, and used for investment for the survival of the family (Hayati, 2012). This was consistent with the element of performance assessment of Islamic perspectives in the aspect of material performance.

Surabaya traditional retailers had run their businesses diligently and felt happy when enjoying the results obtained and fostering trust among others, despite facing the existence of modern stores. This was following the principle of mental performance from the Islamic perspective.

Surabaya traditional retailers also considered working as worship to Allah SWT, which always grateful for the results obtained and remained obedient and consistent with the rules and laws of Allah SWT. This was also consistent with the performance of Islamic businesses in the aspect of spiritual performance (Balog, 2014).

In running its business, traditional retail stores were able to create harmonious social relations in the community, meet the needs of the community with halal products and services, and promote affordable prices. The stores had carried out Islamic business performance in the aspect of fraternal performance (Hoque, 2014).

\section{CONCLUSION}

Based on the result of the analysis and discussion described in the previous chapter, The study of traditional retail stores' survival mechanisms in contending with modern stores was not able to be analyzed using Clark and Scott's survival mechanism theory, so that, the adaptive strategy by Miles and Snow was needed. Adaptive strategies undertaken by Surabaya traditional retailers in achieving competition with those modern ones were in the aspects of defender and reactor strategies. In the aspect of defender strategy, Surabaya traditional retailers did a variety of strategies, such as first, when prices went up, the stores did not enhance the prices too but reduced the profits. Second, retaining customers was conducted by equipping the stores with people's daily needs. Even though the stock was small, the items sold were complete. Third, it was important to promote family relations with buyers. Meanwhile, in the aspect of reactor strategy, the owners responded to the situation without having a long-term strategy design. Their store's responses were reactive and short-term oriented in the form of selling goods by following the tastes of buyers and current trends.

Meanwhile, in carrying out business performance in connection with the survival mechanism, Surabaya traditional retailers contended with the existence of modern stores by meeting the business assessment of the Islamic perspective namely on the aspects of material, mental, spiritual, and fraternal performances. 
Based on the explanation above, regulations related to modern retail stores should be implemented and obeyed by all parties concerned. For traditional retailers, it is necessary to change the paradigm of store management. Traditional retail stores should be not a part-time livelihood but as the main livelihood, so the strategies are needed to increase the store turnover and income. One alternative strategy is the Blue Oceans strategy, which focuses on creativity and innovation carried out continuously.

\section{REFERENCES}

Adhabi, E., \& Anozie, C. B. (2017). Literature review for the type of interview in qualitative research. International Journal of Education, 9(3), 86-97. https://doi.org/10.5296/ije.v9i3.11483

Anupam, D., Vinod, K. \& Saha, G.C. (2010). Retail service quality in context of CIS countries. International Journal of Quality \& Reliability Management, 27(6), 658-683. https://doi.org/10.1108/02656711011054542

Alase, A. (2017). The interpretative phenomenological analysis (IPA): A guide to a good qualitative research approach. International Journal of Education and Literacy Studies, 5(2), 9-19. http://dx.doi.org/10.7575/aiac.ijels.v.5n.2p.9

Ashworth, C. J. (2012). Marketing and organisational development in e-SMEs: Understanding survival and sustainability in growth-oriented and comfortzone pure-play enterprises in the fashion retail industry. International Entrepreneurship and Management Journal, 8(2), 165-201. http://doi.org/10.1007/s11365-011-0171-6

Balog, A. M., Baker, L. T., \& Walker, A. G. (2014). Religiosity and spirituality in entrepreneurship: a review and research agenda. Journal of management, spirituality \& religion, 11(2), 159-186. https://doi.org/10.1080/14766086.2013.836127

Blackmore, K., \& Nesbitt, K. (2013). Verifying the Miles and Snow strategy types in Australian small-and medium-size enterprises. Australian Journal of Management, 38(1), 171-190. https://doi.org/10.1177/0312896212444692

Boyd, N. E., \& Kurov, A. (2012). Trader survival: evidence from the energy futures markets. Journal of Futures Markets, 32(9), 809-836. https://doi.org/10.1002/fut.20543

Clark, G. (2019). Traders versus the state: anthropological approaches to unofficial economies. Routledge.

Dinkominfo of Surabaya. (2018). Minimarket Surabaya dalam Data. https://dinkominfo.surabaya.go.id/index.php?pages=detail_berita\&id_berita $=279$

Disperdagin. http://disperdagin.surabaya.go.id/disdag/2019/01/16/pelepasan-mahasiswakkn-uinsa-untuk-toko-kelontong/

Gros, A. E. (2017). Alfred Schutz on phenomenological psychology and transcendental phenomenology. Journal of Phenomenological Psychology, 48(2), 214-239. https://doi.org/10.1163/15691624-12341329

Hayati, K., \& Caniago, I. (2012). Islamic work ethic: The role of intrinsic motivation, job satisfaction, organizational commitment and job 
performance. Procedia-Social and Behavioral Sciences, 65, 1102-1106. https://doi.org/10.1016/j.sbspro.2014.05.148

Hoque, N., Mamun, A., \& Mohammad Ahshanul Mamun, A. (2014). Dynamics and traits of entrepreneurship: an Islamic approach. World Journal of Entrepreneurship, Management and Sustainable Development, 10(2), 128142. https://doi.org/10.1108/WJEMSD-04-2013-0027

Javed, B., Bashir, S., Rawwas, M. Y., \& Arjoon, S. (2017). Islamic Work Ethic, innovative work behaviour, and adaptive performance: the mediating mechanism and an interacting effect. Current Issues in Tourism, 20(6), 647663. https://doi.org/10.1080/13683500.2016.1171830

Permendag. https://search.hukumonline.com/?query=Peraturan\%20Menteri\%20Perdaga ngan\%20\%20Nomor\%2070\%20tahun\%202013\%20

Prabowo, F. S., \& Rahadi, R. A. (2015). David vs. Goliath: Uncovering The Future of Traditional Markets in Indonesia. Mediterranean Journal of Social Sciences, 6(5), 28. http://dx.doi.org/10.5901/mjss.2015.v6n5p28

Quran Karim. https://litequran.net/al-jumuah

Randall, R. M. (2015). W. Chan Kim and Renée Mauborgne dispel blue ocean myths. Strategy \& Leadership, 43(2), 11-14. https://doi.org/10.1108/SL-012015-0007

Ringwald, K., \& Parfitt, S. (2011). Is reflective practice the key to survival for small independent retailers? Evidence from South-East Wales. Reflective Practice, 12(5), 585-598. https://doi.org/10.1080/14623943.2011.601558

Sunanto, Sandra. (2012). Modern Retail Impact on Store Preference and Traditional Retailers in West Java. AJBR - A Journal about Business in Asia and Beyond. 3 (1-2). https://magscholar.com/asian-journal-of-business-research/archivedissues/ajbr-vol-3-issue-1-2/doi-10-14707ajbr-120007/

Schipmann, C., \& Qaim, M. (2011). Modern food retailers and traditional markets in developing countries: comparing quality, prices, and competition strategies in Thailand. Applied Economic Perspectives and Policy, 33(3), 345-362. https://doi.org/10.22004/ag.econ.108348

Scott, J. C. (2010). The art of not being governed: An anarchist history of upland Southeast Asia. Nus Press.

Tracy, S. J., \& Hinrichs, M. M. (2017). Big tent criteria for qualitative quality. The International Encyclopedia of Communication Research Methods, 1-10. https://doi.org/10.1002/9781118901731.iecrm0016

Usman, M., Shahzad, K., \& Khan, K. (2015). Islamic Work Ethics (IWE): A review of litrature and directions for future research. Journal of Islamic Business and Management, 219(3327), 1-28. https://jibm.org/archieves/volume5issue2/volume5-issue2-article6/

Wahab, K. A., \& Rafiki, A. (2014). Measuring small firm entrepreneur's performance based on Al-Falah. World Applied Sciences Journal, 29(12), 1532-1539. http://www.idosi.org/wasj/wasj29(12)14/7.pdf 
Lilik Rahmawati, Mutimmatul Faidah: Survival of Traditional Retailers: 31 An Islamic Business Perspective

Willis, D. G., Sullivan-Bolyai, S., Knafl, K., \& Cohen, M. Z. (2016). Distinguishing features and similarities between descriptive phenomenological and qualitative description research. Western journal of nursing research, 38(9), 1185-1204. https://doi.org/10.1177/0193945916645499 